\title{
LIQUIDITY RISK AND STOCK RETURN IN LATIN AMERICAN EMERGING MARKETS
}

Francisco Javier Vasquez-Tejos y Prosper Lamothe Fernandez

\begin{abstract}
This study analyzes the impact of liquidity risk on stock returns in four Latin American markets (Chile, Columbia, Mexico, and Peru) between January 1998 and July 2018. Several previous studies have focused on measuring this effect in developed markets and a few in emerging markets, such as Latin American stock markets. In the present study, five liquidity risk measures with a multiple regression model; three have been widely used in previous studies and two were from recently proposed measures. We found evidence of an inverse relationship between liquidity risk and stock performance, which indicates that there exist rewards for investing in less liquid positions and therefore originate new investment strategies. In general, lesser developed or smaller markets have a disadvantage for this type of study, due to lack of access to historical information on stock purchase and sales.
\end{abstract}

Keywords: Liquidity Risk, Stock Returns, Emerging Markets, Latin America, Liquidity Risk Measurements.

DOI: 10.23881/idupbo.020.2-4e 